\title{
EDUCATIONAL PORTALS AS AN OPPORTUNITY TO DEVELOP FORMS OF EDUCATION IN VOCATIONAL EDUCATION
}

\author{
PORTALE EDUKACYJNE SZANSĄ ROZWOJU FORM \\ NAUCZANIA W SZKOLNICTWIE ZAWODOWYM
}
If we teach today's students as we taught yesterday's, we rob them of tomorrow. ${ }^{1}$
John Dewey

\begin{abstract}
The current economic and social changes in the modern world are caused by many factors, but in the light of current social research, those related mainly to the intensive process of transition from the era of Industry 3.0 to the era of Industry 4.0 seem to be dominant. This causes a rapid acceleration in the implementation of systems based on the widespread and avalanche use of new solutions in the field of automation and industrial robotics, elements of artificial intelligence (AI), machine learning (ML) and the Internet of Things (IoT). These rapid technological processes are not always followed by the social and mental processes of entire professional groups, which may lead to economic stratification, but mainly to deepen the processes of digital maladjustment and exclusion (eInclusion).

The panacea for this situation seems to be the development of modern forms of education, with particular emphasis on the needs of vocational education. The issues raised concern both the results of the author's own research on the
\end{abstract}


digitization of Polish schools, as well as the literature review of the OECD research results, the report on the future of workplaces, entitled "The Future of Jobs 2020" and national studies.

\section{STRESZCZenie}

Zachodzące obecnie we współczesnym świecie przemiany gospodarcze i społeczne wywołane są wieloma czynnikami, ale dominujące w świetle aktualnych badań społecznych wydają się te, które związane są głównie z intensywnym procesem przechodzenia z epoki Przemysłu 3.0 do epoki Przemysłu 4.02. Powoduje to gwałtowne przyspieszenie we wdrożeniach systemów opartych na powszechnym i lawinowym zastosowaniu nowych rozwiązań z zakresu automatyki i robotyki przemysłowej, elementów sztucznej inteligencji (AI), uczenia maszynowego (ML) i Internetu rzeczy (IoT). Za tymi gwałtownymi procesami technologicznymi nie zawsze nadążają procesy ogólnospołeczne i mentalne całych grup zawodowych, co może doprowadzić do rozwarstwienia ekonomicznego, ale głównie do pogłębienia procesów niedostosowania i wykluczenia cyfrowego (eInclusion). Panaceum na tę sytuację wydaje się rozwój nowoczesnych form edukacji, ze szczególnym uwzględnieniem potrzeb szkolnictwa zawodowego.

Poruszana problematyka zarówno dotyczy wyników badań własnych autora ${ }^{3}$ na temat procesu cyfryzacji polskich szkól, jak i obejmuje przegląd literatury wyników badań OECD, raport dotyczący przyszłości miejsc pracy pn. The Future of Jobs $2020^{4}$ i opracowania krajowe ${ }^{5}$.

KEYWORDS: educational portals, vocational education, digital transformation, Industry 4.0.

SŁOWA KLUCZOWE: portale edukacyjne, szkolnictwo zawodowe, cyfrowa transformacja, Przemysł 4.0.

\section{WPROWADZENIE}

Obecne czasy przynoszą nam renesans szkolnictwa zawodowego w wielu wymiarach. Po latach skutecznej dewastacji i zapomnieniu o jego roli w funkcjonowaniu gospodarki narodowej doszliśmy do tzw. ściany możliwości, która skutkowała boleśnie na rynku pracy - brakiem wykwalifikowanej kadry zarówno w zakresie świadczonych usług, jak i wsparcia przemysłu. Firmy ratowały się doraźnie zatrudnianiem pracowników zagranicznych, głównie zza naszej wschodniej granicy (z Ukrainy i Białoru- 
si), ale otwarcie rynku niemieckiego na tych pracowników może wkrótce zaowocować tysiącami wakatów nie tylko w budownictwie i usługach.

Stopniowa odbudowa szkolnictwa zawodowego, która nastąpiła po roku 2005, przejawia się obecnie w wieloletnich programach modernizacyjnych poszczególnych województw, w ramach których znaczące środki finansowe przeznaczane są m.in. na budowę lub rozbudowę bazy technicznej tego szkolnictwa ${ }^{6}$, organizację płatnych staży i praktyk zawodowych oraz uruchomienie całych cykli kursów i szkoleń specjalistycznych dla uczniów i nauczycieli. Nadal jednak problemem polskiego szkolnictwa zawodowego na poziomie średnim pozostaje: przestarzały w wielu wypadkach park maszynowy (uczymy, korzystając ze starych, tradycyjnych, a nie nowych i przyszłościowych technologii), wyeksploatowana baza dydaktyczna, a także aspekt przedemerytalnego wieku wielu nauczycieli kształcenia zawodowego (występuje tu dość powszechnie brak możliwości zapewnienia zmiany pokoleniowej, spowodowany głównie czynnikami ekonomicznymi - różnicami w poziomie wynagrodzeń w szkolnictwie średnim oraz przemyśle i usługach).

Poprawa jakości nauczania na poziomie ogólnokształcącym była już od dawna możliwa, m.in. dzięki szerokiemu wykorzystaniu nowych, cyfrowych technologii edukacyjnych. Doświadczenia wielu krajów europejskich (np. brytyjskiej BECTA, portugalskiego projektu MAGELLAN, projektu cyfrowej szkoły w Macedonii, Hiszpanii i wielu innych krajach) wskazują, że wykorzystanie portali do celów edukacyjnych znacznie podnosi jakość kształcenia i to głównie za sprawą przekazu aktualnych i multimedialnych treści. Biorąc pod uwagę aspekt atrakcyjności takich zajęć dla uczniów, należy wskazać, że portale te umożliwiają także prowadzenie zajęć online równolegle dla wielu uczestników, w postaci nie tylko wykładów, ale też zajęć ćwiczeniowych, laboratoryjnych, a nawet praktycznych zajęć warsztatowych. Możliwe jest też obecnie prowadzenie profesjonalnych kursów zawodowych z wykorzystaniem wirtualnej (ang. virtual reality - VR) i rozszerzonej rzeczywistości (ang. augmented reality $-\mathrm{AR})^{7}$ (Sitek, Such-Pyrgiel, 2019).

Szczególnego znaczenia nabrało ostatnio kształcenie zdalne ze względu na okres zagrożenia pandemią koronawirusa. Forma nauczania zdalnego stała się odpowiedzią na pilne zapotrzebowanie społeczne, w tym środo- 
wiska edukacyjnego, w zakresie możliwości prowadzenia zajęć lekcyjnych bez konieczności osobistego, bezpośredniego uczestnictwa w nich zarówno uczniów, jak i nauczycieli.

\section{CHARAKTERYSTYKA ETAPÓW ROZWOJU RÓŻNYCH FORM ZDALNEGO NAUCZANIA}

Analiza dostępnych źródeł literaturowych wskazuje, że po okresie stopniowego rozwoju współpracy szkół na poziomie szkolnictwa podstawowego i średniego (ogólnokształcącego) w postaci tworzenia tzw. gridów (sieci) szkolnych, jak miało to miejsce w województwach opolskim ${ }^{8}$, wielkopolskim ${ }^{9}$ czy też dolnośląskim ${ }^{10}$ (uruchamianych głównie ze środków UE w latach 2007-2013), nastał czas na wymianę informacji i współpracę międzynarodową szkół. European Schoolnet to przykład ogólnoeuropejskiej sieci 34 europejskich ministerstw edukacji z siedzibą w Brukseli, która wprowadziła innowacje w nauczaniu i uczeniu się kluczowych interesariuszy: szkół, nauczycieli, badaczy i partnerów przemysłowych. Uruchomiona w ramach tego programu platforma European Schoolnet Academy ${ }^{11}$ była i jest nadal pierwszą w Europie platformą MOOC (Massive Open Online Course), oferującą wysokiej jakości bezpłatne kursy dla nauczycieli szkół podstawowych i średnich, a także innych profesjonalistów edukacyjnych. Należy przy tym pamiętać, że doświadczenia z wdrażania elementów „eSzkoły” wskazują na możliwość odejścia od formy biernego przyswajania informacji na rzecz czynnego poszukiwania wiedzy.

Badania porównawcze w zakresie skuteczności wykorzystania nowych technologii w edukacji szkolnej (np. brytyjskiej BECTA czy też edukacji Kena Robinsona ${ }^{12}$ ), a także raporty Instytutu Badań Edukacyjnych $\mathrm{MEN}^{13}$ pozwalają na stwierdzenie, że tylko rozwój nowych form edukacji z pełnym wykorzystaniem nowoczesnych narzędzi informatycznych $\mathrm{w}$ połączeniu $\mathrm{z}$ elementami sztucznej inteligencji (ang. artificial intelligence - AI) może przynieść skokowy wzrost jakości procesu edukacyjnego, przede wszystkim w zakresie nowych wyzwań szkolnictwa zawodowego wszystkich szczebli ${ }^{14}$ (Such-Pyrgiel, 2019). 
Kolejnym ważnym krokiem w zakresie wykorzystania narzędzi informatycznych do zdalnej edukacji na szeroką skalę jest realizowany obecnie projekt „Małopolska Chmura Edukacyjna”15 (MChE). Wymierne efekty tego wdrożenia (w latach 2017-2020) wykazały znaczący wzrost zainteresowania tą formą nauczania na poziomie szkół ponadgimnazjalnych. Głównym celem tego projektu jest umożliwienie stałej współpracy wiodących uczelni Małopolski ${ }^{16}$ ze szkołami tego regionu. Efektem tej współpracy jest też podniesienie jakości kształcenia, nauczanie w obszarach nowoczesnej gospodarki oraz rozbudzenie zainteresowania kierunkami studiów zgodnymi ze specjalizacjami regionu. Dzięki realizacji projektu powstało innowacyjne środowisko wsparcia procesów edukacyjnych technologiami informacyjno-komunikacyjnymi (TIK), bazującymi na rozwiązaniach chmurowych (tzw. chmury edukacyjnej) oraz wysokiej jakości komunikacji multimedialnej. Portal MChE udostępnia uczestnikom zajęć online narzędzia do zdalnej współpracy (np. strumieniowanie bieżących spotkań, czaty, grupową edycję dokumentów), dostęp do materiałów dydaktycznych przygotowanych przez nauczycieli akademickich, a także do repozytorium wiedzy ze wszystkich przeprowadzonych online zajęć. Pozwala to nie tylko na nabycie przez uczniów wiedzy merytorycznej, lecz także na przygotowanie do przyszłej pracy zawodowej, w tym z wykorzystaniem nowoczesnych narzędzi informatycznych ${ }^{17}$.

Z jednej więc strony istnieją techniczne możliwości realizacji zajęć online, $\mathrm{w}$ tym $\mathrm{z}$ zastosowaniem profesjonalnych portali edukacyjnych, a $\mathrm{z}$ drugiej istnieje olbrzymie zapotrzebowanie na nowe formy kształcenia zawodowego, zgłaszane przez pracodawców. Dyskusje, jakie toczą się w różnych gremiach stowarzyszeń pracodawców, w tym Krajowej Izby Gospodarczej, wskazują na pilną potrzebę włączenia edukacji zdalnej w proces kształcenia zawodowego, szczególnie w nowo powstających lub rozwijających się zawodach. Technologie cyfrowe umożliwiają już teraz wprowadzanie treści wzbogaconych o elementy zajęć praktycznych, z uwzględnieniem specyfiki poszczególnych zawodów (także w zakresie inteligentnych specjalizacji, ujętych w strategii rozwoju poszczególnych województw). 


\section{OCZEKIWANIA PRACODAWCÓW WOBEC KIERUNKÓW ROZWOJU SZKOLNICTWA ZAWODOWEGO W PRZYSZŁOŚCI}

Za główne problemy natury systemowej stowarzyszenia pracodawców uważają obecnie:

- niedopasowanie potrzeb zatrudnieniowych i dostępności pracowników (np. brak wykwalifikowanych pracowników umysłowych i fizycznych, w tym specjalistów i personelu średniego szczebla oraz robotników wykwalifikowanych, operatorów i monterów, a także istniejące nadwyżki niewykwalifikowanych pracowników fizycznych oraz umysłowych, np. w kategoriach sprzedawców i pracowników biurowych);

- trudności ze znalezieniem odpowiednich pracowników, w tym brak posiadania przez kandydatów odpowiednich kompetencji, doświadczenia i poziomu motywacji do pracy;

- niedobory kompetencyjne, np. konieczność rozwoju najważniejszych kategorii kompetencji: tzw. twardych - umiejętności niezbędnych do wykonywania zadań na danym stanowisku pracy - oraz tzw. miękkich, np. w zakresie organizacji pracy i umiejętności interpersonalnych (komunikacyjnych).

Głównym celem podejmowanych obecnie działań jest podniesienie jakości kształcenia zawodowego na poziomie zarówno szkół średnich, jak i wyższych, poprzez wykorzystanie bogatej bazy dydaktycznej do kształcenia zawodowego oraz olbrzymiego doświadczenia praktycznego polskich uczelni technicznych i ekonomicznych. Ważnym aspektem w realizacji poszczególnych inicjatyw jest nabyte doświadczenie kadry naukowo-dydaktycznej poszczególnych uczelni w prowadzeniu dotychczasowych zajęć online oraz możliwość udostępnienia już zgromadzonych zasobów cyfrowych na portalach edukacyjnych poszczególnych uczelni.

Powstające projekty szkoleniowe są już teraz odpowiedzią na pilną potrzebę wzbogacenia oferty edukacyjnej średnich szkół zawodowych, dzięki m.in. innowacyjnej propozycji przekazu wiedzy i umiejętności praktycznych poprzez udostępnianie technologii informacyjnych i telekomunikacyjnych uczniom i nauczycielom. Istotą tych działań jest też potrzeba przybliżania uczniom szkół średnich osiągnięć naukowo-badawczych uczelni technicz- 
nych, np. kształcących inżynierów z zakresu m.in. automatyki, robotyki, mechatroniki, elektroniki, informatyki i w wielu innych zawodach. Efektem tych działań ma być poznanie szerokich zastosowań i wdrożeń nowoczesnych systemów produkcyjnych, nowych technologii informatycznych, w tym także odpowiedź na zgłaszane potrzeby działających na terenie naszego kraju wielkich korporacji europejskich i międzynarodowych (np. z sektora lotniczego, automatyki przemysłowej, eMobility).

Zdalne nauczanie stało się powszechnie znane, ale realizowane jest w różnych standardach i nie zawsze $z$ uwzględnieniem zasad interoperacyjności systemów informatycznych. Przygotowywane do realizacji projekty powinny więc uwzględniać standardy przyjęte przez m.in. MEN (np. w ramach Zintegrowanej Platformy Edukacyjnej, SIO2 i platformy epodreczniki.pl) oraz gwarantować wysoki standard jakości zajęć dydaktycznych. Należy też pamiętać o tym, aby proponowane rozwiązania technologiczne umożliwiały wykorzystywanie krajowych rozwiązań stosowanych w zdalnej edukacji, co może przynieść znaczące długofalowe oszczędności projektowe. Proponowane obecnie rozwiązania powinny wychodzić naprzeciw oczekiwaniom systemu oświaty w czasach pandemii oraz stwarzać szerokie możliwości wyrównywania szans edukacyjnych uczniom z obszarów niedoinwestowanych edukacyjnie (np. o mniejszym dostępie do różnorodnej oferty edukacyjnej wysokiej jakości).

Przykładem już istniejących w Polsce pilotażowych rozwiązań tego typu jest bez wątpienia projekt Ogólnopolskiej Sieci Edukacyjnej (dalej: OSE) ${ }^{18}$, który zakładał od samego początku stworzenie sieci dostępu do Internetu, łączącej wszystkie szkoły w Polsce (ok. 30,5 tys. podmiotów edukacyjnych). OSE staje się więc stopniowo siecią wirtualną opartą na istniejącej infrastrukturze szerokopasmowej ${ }^{19}$. Operatorem tej sieci jest obecnie NASK (Naukowa i Akademicka Sieć Komputerowa - Państwowy Instytut Badawczy), który stał się także odpowiedzialny za jej utrzymanie oraz wybudowanie brakującej infrastruktury fizycznej. NASK zapewnia również (poprzez operatorów telekomunikacyjnych) dostarczenie szkołom usług dostępu do Internetu o przepustowości co najmniej $100 \mathrm{Mb} / \mathrm{s}$ wraz z usługami bezpieczeństwa i zapewnienie szkołom dostępu do treści edukacyjnych wraz z ich wsparciem w procesie kształcenia umiejętności cyfrowych ${ }^{20}$. Wymiernym 
efektem realizacji tego projektu ma być m.in. zapewnienie cywilizacyjnej zmiany w sposobie kształcenia uczniów poprzez przejście z edukacji analogowej (książki) na cyfrową (korzystanie z treści udostępnionych online), wyrównanie szans edukacyjnych wszystkich uczniów w Polsce, w szczególności tych mieszkających na terenach o niskiej gęstości zaludnienia i uczących się w szkołach o małej liczbie uczniów, dla których dostęp do elektronicznych źródeł wiedzy jest obecnie ograniczony, głównie z powodów technicznych i ekonomicznych. Dodatkowym atutem OSE będzie bez wątpienia zapewnienie transferu wiedzy i doświadczeń pomiędzy nauczycielami z różnych jednostek edukacyjnych (jak ma to miejsce na portalu European Schoolnet).

Należy przy tym pamiętać, że wdrażanie nowoczesnych technologii w nauczaniu zawodowym powinno odbywać się stopniowo. Ma to na celu wyeliminowanie szoku oraz dezorientacji spowodowanej zbyt szybkim i intensywnym przestawieniem się $\mathrm{z}$ tradycyjnych metod nauczania na uczenie za pomocą nowych form przekazu wiedzy ${ }^{21}$. Już w 2014 r. Ruben Puentedura postulował wdrożenie modelu SAMR, ${ }^{22}$ którego nazwa pochodzi od pierwszych liter angielskich oznaczeń tego modelu:

- Substitution (podstawienie) - dotyczy stopniowego dokonywania zmian form nauczania - przejścia $\mathrm{z}$ tradycyjnych na bardziej nowoczesne;

- Augmentation (powiększenie) - polega na zainteresowaniu ucznia korzystaniem z nowoczesnych technologii poprzez uatrakcyjnienie poszczególnych elementów programu nauczania (np. konkursy wiedzy na platformach mobilnych);

- Modification (modyfikacja) - wykorzystanie nowych form i elementów programów nauczania (np. korzystanie z nagranych lekcji z repozytorium wiedzy lub prowadzenie lekcji online $\mathrm{z}$ wykorzystaniem filmów, prezentacji multimedialnych);

- Redefinition (redefinicja) - wykorzystanie całkowitego przekształcenia procesu edukacyjnego poprzez tworzenie elementów wcześniej niemożliwych w nauczaniu (np.: tematyczne fora dyskusyjne, portale edukacyjne, współpraca zdalna pomiędzy jednostkami edukacyjnymi). 
Dzięki poszczególnym etapom modelu SAMR zarówno nauczyciele, jak i uczniowie mogą łatwiej przystosować się do wykorzystywania nowoczesnych technologii informacyjnych, jednocześnie wyrabiając w sobie nawyk samokształcenia i doskonalenia zawodowego (model LLL - ang. lifelong learning). Model SAMR znajduje już dość powszechne zastosowanie na poziomie wyższego szkolnictwa zawodowego. Przyjmując założenie, że tzw. profil praktyczny studiów powinien gwarantować przygotowanie absolwenta szkoły wyższej I stopnia do podjęcia aktywności zawodowej na rynku pracy, i do tego w zawodzie odpowiadającym jego specjalizacji, musimy wymagać efektywnego kształcenia także w zakresie wąsko i precyzyjnie zdefiniowanych umiejętności praktycznych.

\section{WNIOSKI Z OPUBLIKOWANYCH BADAŃ W ZAKRESIE MOŻLIWOŚCI I CELOWOŚCI MASOWEGO WDROŻENIA ELEKTRONICZNYCH FORM NAUCZANIA W SZKOLNICTWIE ZAWODOWYM}

Wyniki analiz porównawczych dostępnych wyników badań jednoznacznie wskazują, że modelowy zakres rzeczowy projektu przyszłej „chmury edukacyjnej” dla szkolnictwa zawodowego powinien zatem uwzględniać następujące elementy:

- budowę systemu informatycznego z wykorzystaniem technologii chmurowych, umożliwiającego wytwarzanie, przetwarzanie, gromadzenie i udostępnianie uczniom średnich szkół zawodowych materiałów dydaktycznych (offline), zdalną dydaktykę prowadzoną przez wybitnych nauczycieli akademickich (online), a także realizację wirtualnych zajęć, w tym w formie: laboratoriów, ćwiczeń, konferencji i zdalnych wizyt studyjnych;

- budowę infrastruktury technicznej w szkołach zawodowych, przystosowaną do radiowego dostępu urządzeń mobilnych i przeznaczoną do odbioru treści edukacyjnych (sieci bezprzewodowe, systemy wideokonferencyjne, tablice multimedialne, pracownie mobilne, rozwiązania dotyczące bezpieczeństwa telekomunikacyjnego itp.);

- utworzenie przez poszczególne uczelnie (lub wybrany centralny ośrodek gromadzenia i przetwarzania danych) repozytoriów materiałów eduka- 
cyjnych oraz poprowadzenie na ich bazie zajęć i ćwiczeń laboratoryjnych, a także realizację wspólnych projektów badawczych i prowadzenie prac dyplomowych uczniów szkół średnich i wyższych technicznych;

- zapewnienie opieki merytorycznej, świadczonej przez pracowników naukowo-dydaktycznych z poszczególnych uczelni, nad programami edukacyjnymi, ze szczególnym uwzględnieniem nowych zawodów, w tym dotyczących produkcji i eksploatacji urządzeń bazujących na wykorzystaniu odnawialnych źródeł energii (OZE) oraz z zakresu elektromobilności;

- zapewnienie procesu doskonalenia zawodowego nauczycieli szkół średnich w zakresie nowych technologii edukacyjnych oraz techniczne doposażenie tych stanowisk w mobilne zestawy wideokonferencyjne;

- zapewnienie doposażenia technicznego stanowisk dydaktycznych szkół wyższych w systemy wideokonferencyjne do nagrywania prowadzonych zajęć (zgodnie ze scenariuszami zajęć opracowanymi na rzecz realizacji programu zajęć obowiązkowych i dodatkowych w określonych zawodach);

- zapewnienie stronom takiego przedsięwzięcia stałej pomocy technicznej i serwisowej.

Wykorzystanie technologii informacyjno-komunikacyjnych (TIK) w procesie nauczania nie oznacza jednak, że technologie mogą częściowo zastąpić, a docelowo wyeliminować nauczyciela. Zmieni się tylko jego rola w tym procesie, gdyż sam nauczyciel będzie przewodnikiem do określania kierunków i sposobów pozyskiwania i utrwalania wiedzy (w tym indywidualizacji form kształcenia). Będzie więc nadal odgrywał w tym procesie istotną rolę, gdyż dzięki jego działaniom uczniowie będą mogli rozwijać swoją wiedzę i doskonalić umiejętności praktyczne. Wymagać to będzie jednak dalszego zdynamizowania procesu doskonalenia zawodowego nauczycieli poprzez zapewnienie im:

- stałych form szkoleniowych (kursowych), w tym online (webinariów) w zakresie: poprawnego posługiwania się terminologią z zakresu TIK, obsługi nowoczesnego sprzętu (w tym urządzeń mobilnych), aktual- 
nego oprogramowania systemowego i narzędziowego (aplikacji sieciowych) wraz z omówieniem aspektów prawnych, etycznych i społecznych dostępu do TIK i korzystania $\mathrm{z}$ tej technologii ${ }^{23}$;

- dostępu online do wysokiej jakości treści edukacyjnych wykorzystujących multimedia (filmy dydaktyczne, transmisje online), a nie jak dotychczas głównie dokumentów w formacie PDF i prezentacji w Microsoft PowerPoint;

- możliwości wykorzystywania jako pomocy dydaktycznych materiałów wytworzonych w postaci wirtualnych laboratoriów przedmiotowych ${ }^{24}$, pomocy dydaktycznych w technologiach druku 3D, dostosowanych do tematyki zajęć (w tym zajęć praktycznych, warsztatowych).

Reasumując, rozwój szkolnictwa zawodowego w Polsce wymaga uwzględnienia nowych form przekazu wiedzy i umiejętności praktycznych. Te nowe formy nauczania w średnim szkolnictwie zawodowym w dużej mierze będą uzależnione od stopnia wykorzystania elektronicznych portali edukacyjnych, które zapewnią najbardziej aktualną wiedzę (weryfikowaną i przekazywaną na bieżąco), dostęp do najbardziej nowoczesnych laboratoriów i technologii dostępnych online, a także mogą zapewnić wysokiej jakości edukację dzięki wykorzystaniu zasobów kadrowych (kadry naukowo-dydaktycznej) polskich uczelni technicznych, ekonomicznych i innych.

\section{Bibliografia}

Angondi, E.K. (2013). Teachers Atittudes and Perceptions on the Use of ICT in Teaching and Learning as Observed by ICT Champions. W: Learning while we are connected, WCCE 2013, 10th IFIP World Conference on Computers in Education, Vol. 1: Research Papers, Toruń: Uniwersytet Mikołaja Kopernika, s. 21-28. ISBN: 9788323130956.

Bulkowski, K. i in. (2019). Absolwenci szkół zawodowych z roku szkolnego 2016/2017. Raport z pierwszej rundy monitoringu losów edukacyjno-zawodowych absolwentów szkół zawodowych, Warszawa: Instytut Badań Edukacyjnych.

Burski, J. i in. (2013). Umiejętności Polaków - wyniki Międzynarodowego Badania Kompetencji Osób Dorostych (PIAAC) - Raport, Warszawa: Instytut Badań Edukacyjnych. 
Ćwiek, M. (2018). Wykluczenie cyfrowe w Polsce na tle Unii Europejskiej, „Ekonomiczne Problemy Usług", nr 131(2). DOI: 10.18276/epu.2018.131/2-21.

Drogosz-Zabłocka, E., Sztanderska, U. (2019). Wykształcenie zawodowe. Perspektywa systemu edukacji i rynku pracy, Warszawa: Wydawnictwo Fundacji Rozwoju Systemu Edukacji. ISBN: 9788365591814.

Flakiewicz, W. (2002). Systemy informacyjne $w$ zarzadzaniu. Uwarunkowania, technologie, rodzaje, Warszawa: Wydawnictwo C.H. Beck. ISBN: 8372470367.

Grądzki, W. (2016), Cyfrowa dydaktyka szansą nowej edukacji. W: M. Zieliński (red.), „Przegląd Nauk Stosowanych”, nr 10. ISSN: 2353-8899.

Jeruszka, U. i in. (red.) (2000). Efektywność kształcenia zawodowego. Kształcenie zawodowe a rynek pracy, Warszawa: IPiSS, seria "Studia i Monografie”. ISBN: 8387890197.

Jemieniak, D., Koźmiński, K.A. (2012). Zarządzanie wiedzą, Warszawa: Wolters Kluwer. ISBN: 9788326435836.

Kocór, M., Strzebońska, A., Dawid-Sawicka, M. (2012). Pracodawcy o rynku pracy. Na podstawie badań zrealizowanych $w 2012$ roku w ramach III edycji projektu Bilans Kapitału Ludzkiego, Warszawa: PARP. ISBN: 9788376331867.

Malamud, O., Pop-Eleches, C. (2011). Home Computer Use and the Development of Human Capital, „Quarterly Journal of Economics”, No. 126, s. 987-1027. DOI: https://doi.org/10.1093/qje/qjr008.

Mumtaz, S. (2000). Factors Affecting Teachers' Use of Information and Communications Technology: a review of the literature, „Journal of Information Technology for Teacher Education", No. 9(3), s. 319-341. ISSN: 0962-029X.

Nonaka, I., Takeuchi, H. (2000). Kreowanie wiedzy w organizacji, Warszawa: Wydawnictwo Poltext.

Oleński, J. (2003). Ekonomika informacji metody, Warszawa: Polskie Wydawnictwo Ekonomiczne. ISBN: 8320814227.

Ortiz Laverde, A.M., et al. (2003). Knowledge Processes: An Overview of the Principal Models, 3rd European Knowledge Management Summer School, San Sebastian.

Penszko, P. (red.) (2013). Ewaluacja ex-post rzadowego programu rozwijania kompetencji uczniów i nauczycieli w zakresie stosowania technologii informacyjno-komunikacyjnych - „Cyfrowa szkoła”, Warszawa: Wydawnictwo IBE.

Sitek, M., Such-Pyrgiel, M. (2019). Cyberkultura. Zagrożenie czy szansa dla edukacji człowieka. W: A. Pawlak, B. Skwarek, J. Stadniczeńko (red.), Prawno-społeczne 
aspekty wychowania $w$ dobie XXI wieku. Zagrożenia, nadzieje, wyzwania, Legnica: Wydawnictwo PWSZ im. Witelona w Legnicy.

Such-Pyrgiel M. (2019), Człowiek $w$ dobie cyfrowej transformacji. Studium socjologiczne, Toruń: Wydawnictwo Adam Marszałek.

Robinson, K. (2016). Creative schools. The grassroots revolution that's transforming education, London: Penguin Books. ISBN: 0143108069.

Sztandar-Sztanderska, U. (red.) (2010). Kwalifikacje dla potrzeb pracodawców, Warszawa: PKPP Lewiatan. ISSN: 2543-585X.

Woźniak, K. (2005). System informacji menedżerskiej jako instrument zarządzania strategicznego w firmie, praca doktorska, Kraków, Akademia Ekonomiczna w Krakowie.

\section{Źródła internetowe}

Balanskat, A., Blamire, R., Kefala, S. (2006). The ICT Impact Report. A review of studies of ICT impact on schools in Europe. European Schoolnet. European Communities. https://www.academia.edu/34505379/The_ICT_Impact_ReportA_review_of_ studies_of_ICT_impact_on_schools_in_Europe (dostęp: 24.10.2020).

Kształcenie na odległość: Poradnik dla szkół, MEN, https://dokumenty.men.gov. pl/ Ksztalcenie_na_odleglosc_\%E2\%80\%93_poradnik_dla_szkol.pdf (dostęp: 24.10.2020).

Piech, K. (2004). Gospodarka oparta na wiedzy jako etap przemian społeczno-gospodarczych krajów transformacji systemowej, https://www.researchgate.net/publication/265592503_Gospodarka_oparta_na_wiedzy_jako_etap_przemian_spoleczno-gospodarczych_krajow_transformacji_systemowej (dostęp: 20.10.2020).

Poland: first forecast of the demand for employees in VET occupations. (2019). https:// www.cedefop.europa.eu/en/publications-and-resources/country-reports/vocational-education-and-training-europe-poland-2018 (dostęp: 24.10.2020).

The Future of Jobs 2020, https://www.weforum.org/reports/the-future-of-jobs-report-2020 (dostęp: 20.10.2020).

www.epodreczniki.pl (dostęp: 24.10.2020).

www.eszkola.tvp.pl (dostęp: 24.10.2020).

www.etwinning.pl/zdalna-edukacja-z-etwinning (dostęp: 24.10.2020).

www.gov.pl/web/zdalnelekcje (dostęp: 24.10.2020).

www.lektury.gov.pl (dostęp: 24.10.2020).

www.ore.edu.pl (dostęp: 24.10.2020). 


\section{Endnotes}

1) John Dewey: „If we teach today's students as we taught yesterday's, we rob them of tomorrow". Źródło: https:/quotepark.com/pl/autorzy/john-dewey/ (dostęp: 24.07.2020).

2) The Future of Jobs 2020, https://www.weforum.org/reports/the-future-of-jobs-report-2020 (dostęp: 20.12.2020).

3) Grądzki, W. (2016). Cyfrowa dydaktyka szansa nowej edukacji. W: M. Ziemiński (red.), „Przegląd Nauk Stosowanych”, nr 10, s. 43-58.

4) The Future of Jobs 2020, https://www.weforum.org/reports/the-future-of-jobs-report-2020 (dostęp: 20.10.2020).

5) Ćwiek, M. (2018), Wykluczenie cyfrowe w Polsce na tle Unii Europejskiej, „Ekonomiczne Problemy Usług", nr 131(2), https://wnus.edu.pl/epu/pl/issue/983/article/15928/ (dostęp: 24.07.2020).

6) Programy typu „Zintegrowany rozwój szkolnictwa zawodowego” w poszczególnych województwach finansowane ze środków regionalnych programów operacyjnych (perspektywa UE na lata 2014-2020), http://edukacja.warszawa.pl/ projekt-zintegrowany-rozwoj-szkolnictwa-zawodowego (dostęp: 24.07.2020).

7) Sitek, M., Such-Pyrgiel, M. (2019). Cyberkultura. Zagrożenie czy szansa dla edukacji człowieka. W: A. Pawlak, B. Skwarek, J. Stadniczeńko (red.), Prawno-społeczne aspekty wychowania $w$ dobie XXI wieku. Zagrożenia, nadzieje, wyzwania, Legnica: PWSZ w Legnicy, s. 80-83.

8) Opolska eSzkoła, https://www.eszkola.opolskie.pl/Strony/Witamy.aspx (dostęp: 24.07.2020).

9) eSzkoła-Moja Wielkopolska, https://www.umww.pl/departamenty_departament-edukacji-i-nauki_projekty-edukacyjne-prowadzone-w-ramach-pokl_eszkola-moja-wielkopolska (dostęp: 24.07.2020).

10) Projekt „Dolnośląska e-szkoła”, http://www.umwd.dolnyslask.pl/edukacja/projekty-rpo-i-ewt/dolnoslaska-e-szkola/ (dostęp: 24.07.2020).

11) http://www.eun.org/professional-development/academy (dostęp: 24.07.2020).

12) Robinson, K. (2016). Creative schools. The grassroots revolution that's transforming education, London: Penguin Books.

13) Penszko, P. (red.) (2013). Ewaluacja ex-post rządowego programu rozwijania kompetencji uczniów i nauczycieli $w$ zakresie stosowania technologii informacyjno-komunikacyjnych - „Cyfrowa szkoła”, Warszawa: Wydawnictwo IBE. 
14) Such-Pyrgiel, M. (2019). Człowiek $w$ dobie cyfrowej transformacji. Studium socjologiczne, Toruń: Wydawnictwo Adam Marszałek, s. 154-158.

15) Projekt AGH - Małopolska Chmura Edukacyjna, https://www.ki.agh.edu.pl/projekty/malopolska-chmura-edukacyjna (dostęp: 24.07.2020).

16) Pilotażowe wdrożenie modelu chmury edukacyjnej gwarantowało udział wiodących uczelni Małopolski (np. Akademii Górniczo-Hutniczej, Politechniki Krakowskiej, Uniwersytetu Ekonomicznego, Uniwersytetu Jagiellońskiego, Uniwersyteut Pedagogicznego, Uniwersytetu Rolniczego).

17) https://portal.mche.edu.pl/pages/index.html (dostęp: 24.07.2020).

18) https://www.gov.pl/web/cyfryzacja/ogolnopolska-siec-edukacyjna1 (dostęp: 24.07.2020).

19) Wybudowanej w całości ze środków komercyjnych, jak i przy udziale dofinansowania ze środków publicznych, w szczególności Programu Operacyjnego Polska Cyfrowa.

20) https://www.gov.pl/cyfryzacja/konsultacje-ustawy-o-ogolnopolskiej-sieciedukacyjnej (dostęp: 24.07.2020).

21) Polak, M., Model SAMR, czyli o technologii w nauczaniu (https://edunews.pl/badania-i-debaty/badania/2736-model-samr-czyli-o-technologii-w-nauczaniu) (dostęp: 24.07.2020).

22) The Substitution Augmentation Modification Redefinition (SAMR) Model: a Critical Review and Suggestions for its Use, https://link.springer.com/article/10.1007/ s11528-016-0091-y (dostęp: 24.07.2020).

23) Sysło, M. (2012). Technologia informacyjna w edukacji, Wrocław: Instytut Informatyki Uniwersytetu Wrocławskiego, s. 21.

24) http://wlf-info-platforma.wwsi.edu.pl/ (dostęp: 24.07.2020). 
